\title{
Papan Permainan Puzzle Sebagai Media Pembelajaran Aksara Jawa Pada Anak Usia Dini
}

*Ahmad Ghazali1, Dhevin Kawistoro Ngabekti' ${ }^{2}$, Nanda Putri Andriani ${ }^{3}$

Fakultas Seni Rupa dan Desain, Institut Seni Indonesia Surakarta1,2,3

\begin{abstract}
Javanese, one of more than 300 languages in Indonesia. In order to understand the legacy of our ancestors, the role of the Javanese script is quite significant so it is important to learn and understand. At this time, the

Artikel History

Dikirim: 3 Mei 2021

Revisi : 10 Mei 2021

Diterima:25 Mei 2021
\end{abstract}

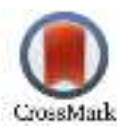

Corresponding author.

E-mail: ahmadghazali47@gmail.com

\begin{abstract}
Abstrak
Bahasa Jawa, salah satu dari 300 lebih bahasa yang ada di Indonesia. Untuk memahami dibalik peninggalan nenek moyang kita, peran aksara Jawan cukup signifikan pengaruhnya sehingga penting untuk dipelajari dan dipahami. Ketertarikan anak usia dini pada kebudayaan Indonesia pada saat ini mulai kurang dan semakin lama dapat menyebabkan kebudayaan Indonesia ditinggalkan. Rendahnya tingkat kemampuan membaca dan menulis aksara Jawa dikarenakan oleh beberapa faktor yaitu, minat, guru, metode pembelajaran, serta sarana dan prasarana media pembelajaran. Menerapkan metode pembelajaran aksara Jawa sejak usia dini dengan menggunakan media permainan puzzle ini diharapkan generasi mendatang dapat menguasainya dan dapat menjaga kelestarian budaya-budaya yang dimiliki oleh negara tercinta ini. Metode penelitian yang dipilih yaitu kualitatif deskriptif dengan mengumpulkan data melalui proses studi literatur yang mana pengumpulan data berasal dari buku buku dan dokumen terkait dengan bahasan artikel ini.
\end{abstract}

Kata Kunci : Aksara jawa, Puzzle, Pembelajaran, Belajar, Metode 


\section{PENGANTAR}

Bahasa Jawa merupakan salah satu dari banyaknya bahasa daerah yang dimiliki oleh Indonesia. Bahasa Jawa digunakan oleh masyarakat di Pulau Jawa, yaitu Jawa Tengah, Jawa Timur, serta pesisir Jawa Barat dengan berbagai karakeristik yang berbeda. Bahasa Jawa yang digunakan di daerah Surakarta memiliki kosa kata dan pemakaian kata yang berbeda dengan daerah Surabaya. Dalam dunia pendidikan, daerah yang menggunakan Bahasa Jawa terdapat mata pelajaran Pendidikan Bahasa Jawa bagi jenjang sekolah dasar sampai menegah atas. Dalam mata pelajaran tersebut tidak hanya mempelajari bahasanya saja, namun terdapat berbagai aspek budaya jawa lainnya seperti pewayangan, unggah-ungguh atau sopan santun, puisi jawa atau geguritan, tembang macapat, serta huruf jawa atau aksara Jawa.

Menurut Djati Prihananto (2011), aksara Jawa merupakan aksara atau huruf yang digunakan untuk menulis Bahasa Jawa. Aksara Jawa adalah salah satu kebudayan Jawa yang harus dilestarikan. Aksara Jawa dapat digunakan sebagai sarana dalam memahami peninggalan naskah-naskah kuno sastra Jawa dan peninggalan jawa kuno lainnya. Agar memahami makna dibalik peinggalan leluhur kita, peran aksara Jawa cukup berpengaruh sehingga penting untuk dipelajari dan dipahami. Upaya pelestarian Aksara Jawa banyak dilakukan oleh pemerintah, salah satunya adalah memasukkan aksara Jawa dalam kurikulum pendidikan.

Ketertarikan anak usia dini terhadap kebudayaan Indonesia saat ini semakin memudar. Anak-anak lebih suka menggunakan gawai dan internet yang di dalamnya terkandung banyak sekali informasi. Sehingga budaya asing lebih dikenal daripada budaya Indonesia itu sendiri. Rendahnya kemampuan membaca dan menulis aksara Jawa disebabkan oleh beberapa faktor yaitu, minat, guru, metode pembelajaran, serta sarana dan prasarana termasuk media pembelajaran. Dalam dunia pendidikan Indonesia, metode pembelajaran yang digunakan saat ini sudah cukup beragam. Misalnya dengan melalui cara bermain sambil belajar untuk anak usia dini. Upaya untuk mengenalkan dan menumbuhkan rasa cinta terhadap budaya jawa kepada anak usia dini, dapat dilakukan metode bermain sambil belajar dengan menggunakan media puzzle.

Puzzle merupakan salah satu permainan edukatif untuk anak-anak. Puzzle menurut Suciaty (2010) adalah permainan yang bisa dimainkan mulai dari 12 bulan. Puzzle sendiri termasuk ke dalam salah satu jenis papan permainan atau boardgame. Boardgame 
merupakan salah satu jenis permainan tertua di dunia yang telah ditemukan pada masa predinasti dan dinasti awal kerajaan Mesir kuno (sekitar 3500-3100 SM). Menurut Mike Scorviano (2010), boardgame adalah jenis permainan dimana alat-alat atau bagian-bagian permainan ditempatkan, dipindahkan, atau digerakkan pada permukaan yang telah ditandai atau dibagi-bagi menurut seperangkat aturan.

Puzzle dapat memberikan kesempatan belajar yang banyak, selain untuk menarik minat dan membina semangat belajar dalam bermain. Permainan ini dapat dilakukan di mana saja. Permainan puzzle memiliki kemampuan untuk melatih kecerdasan logis, melatih gerak motorik anak, serta logika berpikir. Dengan menggunakan media puzzle, upaya untuk pengenalan dan melestarikan Aksara Jawa akan lebih mudah diterima. Hal ini tentu juga akan berpengaruh pada kebiasaaan anak usia dini dalam hal bersosialisasi. Puzzle aksara Jawa dapat membantu anak untuk mengurangi kebiasaan dalam memainkan gawai karena dengan memainkan puzzle ini akan menimbulkan rasa senang dan ingin kembali memainkannya.

\section{PEMBAHASAN}

Indonesia mempunyai beragam budaya, bahasa, maupun aksara, hingga saat ini tercatat Indonesia mempunyai ratusan aksara namun hanya beberapa yang dapat ditemui pada saat ini dan apabila tidak dilestarikan dan dikenalkan sejak dini maka dikhawatirkan aksara aksara yang tersisa akan menjadi sejarah belaka. Di Indonesia khususnya di pulau jawa terdapat aksara jawa yang mungkin tidak asing bagi sebagian besar masyarakat yang berada di provinsi jawa timur dan jawa tengah yang mana sudah dikenalkan sejak sekolah dasar dan berlanjut sampai sekolah menengah pertama. Meskipun sudah ditanamkan sejak dini cuma sedikit dari generasi muda yang masi menghafal atau mengingat aksara jawa tersebut.

\section{A. Metode Efektif Belajar Aksara Jawa}

Pembelajaran mengenai aksara jawa sudah dimulai sejak pertengahan Sekolah Dasar yaitu anak dengan rentang usia 8-10 tahun. Guru mulai mengenalkan anak muridnya dengan aksara jawa menggunakan buku yang bernama pepak bahasa jawa yang berisi konten edukatif mengenai bahasa jawa. Meskipun begitu cara guru dalam menyampaikan materi pembelajaran dirasa kurang menarik dan monoton yang mana hanya diinstruksikan untuk menghafal dan menulis yang berakibat tidak efektifnya materi aksara jawa yang terserap karena tidak adanya minat belajar dalam siswa yang akhirnya berdampak siswa terbebani dan merasa terpaksa dalam kegiatan belajar 
Faktanya ilmu bahasa seperti aksara jawa akan dipelajari secara optimal kepada anak berusia dini. Usia 5-6 tahun dikategorikan sebagai rentang usia dini bagi anak. Usia demikian merupakan terjadinya pematangan fungsi - fungsi psikis maupun fisik yang siap merespon stimulasi yang diberikan oleh lingkungan. Maka dari itu aksara jawa perlu dikenalkan sejak usia dini yang harapannya generasi muda yang akan datang dapat melestarikan dan mengenal akan adanya aksara jawa. Mengenai hal ini metode pembelajaran aksara jawa yang kreatif sangat diperlukan agar tidak membebani anak dalam belajar. Penulis memiliki gagasan ide mengenai metode belajar sambil bermain yang membuat anak menjadi antusias dan fokus dalam belajar aksara jawa. Metode ini diaplikasikan dengan menggunakan media papan permainan puzzle aksara jawa.

\section{B. Puzzle Aksara Jawa}

Papan permainan puzzle ini cocok untuk anak usia dini karena tingkat kesulitannya yang terbilang mudah. Sistem permainannya pun juga simpel, anak hanya perlu mencocokan bentuk potongan aksara jawa di papan yang memiliki bentuk soket yang sama dengan potongan papan aksara jawa. Dengan metode ini pembelajaran yang awalnya membosankan menjadi menyenangkan karena aday nedia pembelajaran baru berupa papan permainan puzzle.

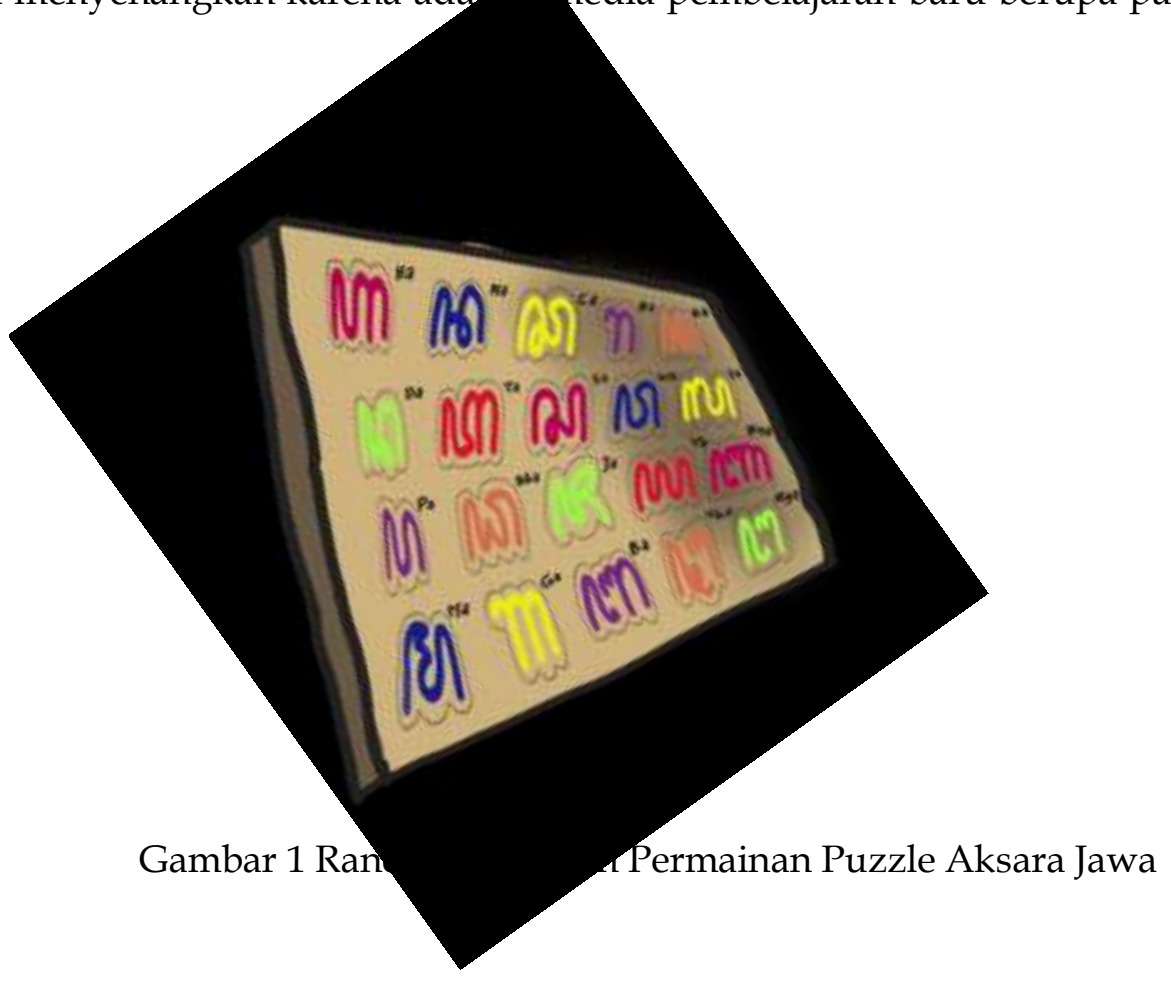




\section{Manfaat Papan Permainan Puzzle Aksara Jawa}

Papan permainan puzzle aksara jawa ini tidak hanya digunakan untuk belajar aksara jawa namun dapat juga digunakan untuk

1. melatih logika anak

2. membantu meningkatkan motorik halus pada anak anak

3. membantu melatih koordinasi antara tangan dan mata

4. melatih kesabaran anak

5. meningkatkan kemampuan anak dalam bersosialisasi

6. melatih ketrampilan anak dalam memecahkan masalah maupun mencari solusi.

Dengan adanya puzzle yang mengimplementasikan aksara Jawa ini maka akan meningkatkan minat dan semangat belajar anak usia dini terhadap aksara Jawa. Secara tidak langsung dengan melihat dan memainkan puzzle, anak akan mengingat bentuk dari Aksara Jawa sehingga hal ini akan menjadi sarana pengenalan dan pelestarian Aksara Jawa untuk anak usia dini.

\section{Strategi yang Ditempuh}

Langkah strategis yang harus ditempuh agar aksara jawa tetap terjaga dan lebih mudah untuk dipelajari dijabarkan dalam alur berikut :

1. Mengenalkan dan mulai menerapkan metode pembelajaran aksara jawa sejak usia dini dengan menggunakan papan permainan puzzle aksara jawa dengan harapan generasi muda yang lebih menguasai dan tetap melestarikan budaya aksara jawa.

2. Membuat dan merancang sekreatif mungkin hal yang berkaitan dengan visual dari papan permainan puzzle aksara jawa dan diharapkan cocok dengan selera anak anak.

3. Pendistribusian penjualan papan permainan puzzle yang mencakup TK, Sekolah Dasar, Toko buku, dan Toko mainan di seluruh Indonesia.

\section{KESIMPULAN}

Bahasa Jawa, salah satu dari 300 lebih bahasa yang ada di Indonesia. Untuk memahami dibalik peninggalan nenek moyang kita, peran aksara Jawan cukup signifikan pengaruhnya sehingga penting untuk dipelajari dan dipahami. Ketertarikan anak usia dini pada kebudayaan Indonesia pada saat ini mulai kurang dan semakin lama dapat menyebabkan kebudayaan Indonesia ditinggalkan. Rendahnya tingkat kemampuan membaca dan menulis aksara Jawa dikarenakan oleh beberapa faktor yaitu, minat, guru, 
metode pembelajaran, serta sarana dan prasarana media pembelajaran. Menurut Suciaty, puzzle adalah permainan yang dapat dimainkan mulai dari anak usia 12 bulan, 48 minggu atau 1 tahun. Puzzle dapat memberikan kesempatan belajar yang cukup banyak, selain untuk menarik minat dan membina semangat belajar dalam permainan ini dapat dilakukan di mana saja. Permainan ini dapat mengasah kemampuan untuk melatih kecerdasan logis, melatih kemampuan untuk gerak motorik anak dan serta logika berpikir. Hal ini tentunya sangat berpengaruh pada kebiasaan anak usia dini dalam bidang bersosialisasi. Faktanya ilmu bahasa, dapat dipelajari dengan mudah dan sangat optimal ketika anak berusia dini. Anak usia 5-6 tahun dikategorikan sebagai rentang usia dini bagi anak, dengan demikian terjadinya pematangan fungsifungsi psikis maupun fisik yang siap merespon stimulan yang diberikan oleh lingkungan. Menerapkan metode pembelajaran aksara Jawa sejak usia dini dengan menggunakan media permainan puzzle ini diharapkan generasi mendatang dapat menguasainya dan dapat menjaga kelestarian budaya-budaya yang dimiliki oleh negara tercinta ini.

\section{DAFTAR PUSTAKA}

Amstrong, Thomas. (2005). Setiap Anak Cerdas: Panduan Membantu anak Belajar dengan Memanfaatkan Multiple Intelegent. Jakarta: Gramedia

Brewer An Jo. (2007). Introduction to Early Childhood Education Prescholl though primary Grades. Sixt Edition: University of Massachusetts Lowel

Hamzah B Uno. (2010). Model Pembelajaran Menciptakan Proses Belajar Mengajar yang kreatif dan efektif. Jakarta: Bumi Aksar

Marantika, Silviana Devi. (2015) .Upaya Meningkatkan kemampuan membaca aksara jawa dengan multimedia senenge sinau aksara jawa pada siswa kelas 4 A SDN gedongkiwo yogyakarta. Universitas Negeri Yogaykarta

Gunawan, eko.(2018).Cepat terampil membaca aksara jawa (pengenalan aksara, penerapan sandhangan, pemerapam pasangan).Yogyakarta : Deepublish

Moeslichatoen, R. (2004). Metode Pengajaran di Taman Kanak-kanak. Jakarta. PT. Rineka Cipta. 
Oktaviana, dina. 2017. Pengaruh media pembelajaran puzzle subtema ketampakan rupa bumi terhadap partisipasi dan prestasi belajar siswa kelas 3 SD Negeri 1 rancamaya. Purwokerto : Universitas muhammadiyah Purwokerto

Sudarsana, Pendidikan Anak Usia Dini Berkarakter, Yogyakarta: Genius Publiser, 2014.

Suyadi, Psikologi Belajar Pendidikan Anak Usia Dini, Yogyakarta: Pedagogia, 2010. 